\title{
EFFECT OF FINANCIAL LITERACY, RISK ATTITUDE AND SAVING MOTIVES TO DISPOSITION BIAS ON MUTUAL FUNDS INVESTORS
}

\author{
Jennifer Saputra1, Dewi Astuti ${ }^{2}$, Dewi Pertiwi ${ }^{3}$ \\ 1,2,3 Finance and Investment Program, Faculty of Business and Economics, Petra Christian University \\ Jl. Siwalankerto 121-131, Surabaya \\ E-mail: 1jennifersaputra@gmail.com; ${ }^{2}$ dewi@petra.ac.id; ${ }^{3}$ dewi.pertiwi@petra.ac.id
}

\begin{abstract}
Investment is significant to prepare human needs in the future. To make investment decisions, investors will try to make their decisions as rationally as possible. However, one cannot deny that some irrational factors or biases also influence investment decision-making. This study examines financial literacy, risk attitude, and saving motives on disposition bias of mutual fund investors. The sample used is mutual fund investors, and the respondents themselves make decisions to sell or buy mutual funds. The total of respondents is 116 respondents. The regression method used in this study is binary logistic regression using SPSS software. This study found that financial literacy and risk attitude has a significant effect on disposition bias. Meanwhile, the variable saving motives have no considerable impact on disposition bias.
\end{abstract}

Keywords: Financial Literacy, Risk Attitude, Saving Motives, Disposition Bias, Mutual Fund Investors, Bias.

\section{INTRODUCTION}

Investment is usually a long-term investment with the hope of getting benefits in the future (Sunariyah, 2003). Investment is divided into two, namely real asset investment and financial asset investment. Real asset investment is a tangible investment (can be seen physically) or tangible assets (Sunariyah, 2004). Investment in financial support is an investment in the form of intangible (intangible assets). Investment is significant to prepare for future needs such as; funds for unexpected needs, education funds, funds when they fall ill, and pension funds (Ahmad, 2004). In addition, investing is also used to protect assets from the threat of unpredictable inflation. Some of the obstacles an investor faces in investing are limited funds, lack of known investment products, lack of knowledge of investment, and lack of ability to manage an investment, which makes investors choose to invest in mutual funds (Rahmayanti, 2018). Mutual funds are a combination of several financial asset investments or referred to as a portfolio. Mutual funds are tailored to the risk profile and financial goals of investors.

According to Awan \& Arshad (2012), mutual funds have several advantages: they are managed by a professional, diversify risks, reduce transaction costs, and are liquid. In mutual funds, there are portfolio choices that will minimize the risk because funds or wealth in mutual funds are invested in various types of securities so that the risk is also spread. In other words, the risk that will be obtained is not as big as when an investor buys shares or securities individually so that investors who are included in the riskaverse group can invest comfortably in mutual funds. According to the Financial Services Authority, mutual funds are an investment alternative for the investor community, especially small investors and investors who do not have much time and expertise to manage these investments. Mutual funds are designed to raise funds from investors who desire to invest but do not have much time and knowledge. The mutual funds that are widely known by the public in Indonesia are conventional mutual funds, which are mutual funds that investors can buy or resell at any time depending on the investment objectives, time frame, and risk profile of the investor (Kawitan, 2015).

Wu, Dutta, and Huang (2018) explain that even though mutual fund products can be said to have a safer or less risky level of return on safety, they can still lead to the possibility of disposition bias for investors. The problem scenario that allows for disposition bias is a loss in one of the products purchased in mutual funds. When investors find that there has been a loss for one of the products purchased, the investor will experience disposition bias because it is not possible to cut loss on only one product. This creates a disposition bias when there is a loss in one of the products. From the description explained by Wu, Dutta, and Huang (2018), it is clear that disposition bias occurs because of the risk attitude of investors, the level of financial literacy, and saving motives.

In making decisions, every investor is influenced by investors who always try to make decisions rationally. However, in reality, investors are also affected by the irrational side, which is influenced by disposition 
bias or deviations (Budiarto, 2017). This is an irrational side that causes investor to often make unexpected decisions (Cholidia, 2017).

Disposition bias is influenced by how investors react to the mutual funds they own, irrational and hasty reactions of investors can have a negative impact on the mutual funds owned, for example, investors who are too hasty to sell or sell mutual funds when the NAV of the mutual fund product is increasing in future. The main explanation for disposition bias is based on prospect theory. Prospect theory explains the occurrence of cognitive bias that affects decision-making under conditions of uncertainty and risk. Individuals will be risk-averse or they will like risk, depending on the problem at hand (Kahneman \& Tversky, 1979). Disposition bias can occur when mutual fund investors rush to decide to sell mutual funds. In this case, several factors are needed that can help an investor to reduce his disposition bias, namely the need for financial literacy, risk attitudes, and saving motives (Jonsson, Söderberg, \& Wilhelmsson, 2017).

\section{LITERATURE REVIEW}

\section{Behavioral Finance}

Behavioral finance is a science that studies how humans disclose and react to existing information to make decisions that can optimize returns by taking into account the inherent risks, such as elements of human attitudes and actions that are determining factors in investing (Lintner, 1998). Behavioral finance is a person's psychological application of finance (Pompian, 2006). Financial behavior is fundamental to study because the attitude of investors in making investment decisions is different from one another.

According to Ricciardi \& Simon (2000), behavioral finance tries to explain and increase the understanding of the patterns of investors' reasons, including emotional aspects and the degree of these aspects in influencing the decision-making process. Nofsinger (2001) defines behavioral finance, studying how humans behave in a financial determination. According to Thaler (1999), financial behavior is not only related to the existing foundations of financial literacy and economic law but is also influenced by psychological factors. In previous studies, the psychological factors applied by investors were risk attitudes and saving motives. Behavioral finance is built on various assumptions and ideas from economic behavior. Emotional involvement, traits, preferences, and different kinds of things inherent in humans as intellectual and social beings will interact and underlie the emergence of decisions to take action (Ricciardi, 2000).

\section{Financial Literacy}

Financial literacy is knowledge and understanding of financial concepts used to make effective financial choices, improve individuals and groups' financial well-being, and participate in economic life (PISA, 2012). Financial literacy is the ability to evaluate new and complex financial instruments and make financial instruments judgments (Mandell, 2007). Financial literacy is described as a person's ability to plan finances well by utilizing savings and investments to accumulate wealth, followed by appropriate preventive measures against the risk of loss and proper financial distribution at the final stage (Mahdzan \& Victorian, 2013).

Financial literacy is important in making sound financial decisions (Lusardi, Mitchell, \& Curto, 2010). Low financial literacy is a serious problem because it can have a negative impact on financial behavior (Widjaja \& Pertiwi, 2021). Low financial literacy can also lead to financial fraud practices and unfair competition in the financial market, which can become a barrier to an effective financial intermediation (Hidajat, 2015; Wahono \& Pertiwi, 2020). According to Jonsson, Söderberg, and Wilhelmsson (2018), financial literacy is divided into three types: technical financial knowledge, mutual fund knowledge, and market knowledge.

\section{Risk Attitude}

Risk Attitude is an action chosen based on the idea of uncertainty that has a positive or negative effect on the goal, namely the attitude to accept and face risk (risk propensity) or avoid risk (risk aversion) (Rohrmann, 2004). Avoiding the risk, facing risk, tolerating risk, and being neutral to risk are forms of response to perceptual-driven uncertainty (Hillson \& Murray-Webster, 2005). This response is known as 
an attitude to risk or risk attitude. Risk attitude is an action chosen based on thinking about the uncertainty that positively or negatively affects goals (Hillson \& Murray-Webster, 2006). Risk attitude is selected by individuals or groups when dealing with risk situations that are influenced by various factors. Some investors tolerate risk when faced with investments that generate high returns (Madura, 2016).

The term risk attitude describes a decision-making situation where a limited number of outcomes exist for decisions made under uncertainty (Widjaja \& Pertiwi, 2021). Risk-averse individuals prefer less profitable options than other options that are beneficial but with a higher risk. Evidence shows that men are more confident and less risk-averse in managerial decision-making. Other studies have found that women have a lower self-perceived ability to make complex financial decisions (Chowdhury \& Endres, 2005; Jones \& Tullous, 2002) and are less risky than men in financial decision-making situations (Powel \& Ansic, 1997).

\section{Saving Motives}

Saving motives have been studied since the time of Keynes. Generally, explanation refers to the circumstances in which the individual experiences a journey to obtain a future destination. Warneryd (1995) states there are 4(four) saving motives. The first level is saving as a continuous habit. This condition is not related to a specific purpose. The second motive often referred to as the motive for preventive action, is related to uncertainty in the future. The third motive is the inheritance motive, which means that savings are used after the death in the family. The fourth motive is the profit motive, which means the desire to get additional income from your savings. This shows that the motivation to save as a sustainable habit and preventive measures contributes significantly to the total variant of money saved.

Lindqvist (1981) says there is a structure in saving motives, namely, at the lowest level is the need to regulate cash for short-term goals. The second level is the need to hold money as a measure of preventive action. The third level is the need to buy very expensive goods. and the last level is the need to regulate financial accumulation. These levels vary depending on the different characteristics of the saver. Dhavaney et al. (2007) extend the hierarchical theory of saving motives. It examines the possibility of movement from a low level of need to a higher level of need and examines the factors that influence the likelihood of such activity. Saving motives in a hierarchy (from low to high) are from conditions of no savings towards physical needs (basic), security (safety), resilience/security (security), social / love, esteem/ lux, self-actualization.

\section{Disposition Bias}

Disposition bias is born from the prospect theory developed by Shefrin and Statman (1985) which states that there are differences in gain and loss. The study found psychological factors that influence disposition bias: mental accounting, avoiding regret aversion, self-control, and tax consideration in decision making. This study suggests not using tax consideration because it cannot explain loss and gain realization patterns. The results of this study generally found a sense of wanting to avoid regret made by investors and trying to find pride in their assets, thus influencing investors' decisions.

Prospect theory is a theory of decision-making in risky conditions. Decisions are made based on the circumstances that occur. The situation is in a state of uncertainty, where it is difficult to predict the consequences or outcomes of these events. The decisions taken involve internal conflicts over value trade-offs, which are difficult choices when conflicting values and goals. The main explanation for disposition bias is based on prospect theory, namely the occurrence of cognitive bias that affects decision-making in conditions of uncertainty and risk. Cognitive bias is a deviation in understanding, processing, and making decisions on information or facts. Prospect theory states that most investors will avoid risk if faced with an expectation of a return on their investment. Still, when faced with the possibility of getting a loss in their investment, most of them often decide to take risks, this is because they feel reluctant to experience it. The individual will be risk-averse or will like risk depending on the problem at hand (Kahneman and Tversky, 1979).

\section{The Relationship Between Concepts}

1) Influence of Financial Literacy on Disposition Bias

Financial literacy is financial knowledge and skills to apply this financial knowledge (Lusardi \& Mitchell, 2007). The higher a person's level of financial literacy, the wiser that person is in making decisions. A 
person's level of financial literacy can be influenced by several factors, including gender, age, and experience. According to Lusardi \& Mitchell (2007), financial literacy affects investment decisions and reduces cognitive bias. Investors who have good financial literacy will avoid deviant behavior and act more rationally.

2) The Effect of Risk Attitude on Disposition Bias

Research by Daniel (1998) shows that the psychological factors of risk perception and risk attitude can influence investors in making investment decisions due to a subjective attitude towards risk and investment income itself. Risk attitude shows whether the investor is more courageous, tolerant, or avoidant when faced with risk. The attitude of investors towards risk depends very much on the preferences of the investor concerned for risk. Harris, Jenkins, \& Glaser (2006) reveal that an individual's risk attitude is essential in understanding risk-related behavior and decisions is a good predictor of risk-related behavior and choices.

3) The Effect of Saving Motives on Disposition Bias

Future-oriented societies certainly have financial needs in the future, such as buying a house, saving for an unexpected illness or becoming unemployed, and saving for retirement. People will hold on to be able to get their needs. Still, when viewed from various aspects that affect the amount of savings such as administrative costs, inflation can cause interest income to decrease, and so on, people choose another alternative, namely investment.

Saving motives are related to investing in depreciable fixed assets such as land, houses, factories, and equipment. Loss of value for money in the form of depreciation of new assets and debt will be appropriately offset by saving in the form of investment in financial assets (Horioka \& Watanabe, 1997). Investments that suit this need are mutual fund investments, where there is diversification of risk and low transaction costs, are managed by an investment manager and are easy to trade. One's saving motives influence their investment decision-making. If the motive that is owned is luxury, children's education, and so on, they will be careful and won't be hasty in making investment decisions. In other words, the person's disposition bias can be said to be low. Low disposition bias indicates that an investor knows what risks to face and chooses to put their funds in savings assets. Savings are considered as the safest alternative means when an investor has low disposition bias.

\section{Thinking Framework}

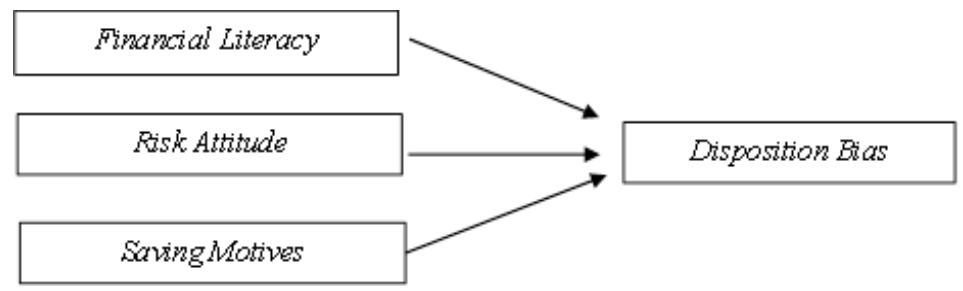

Figure 1. Research Model Framework

\section{Hypothesis}

1. Financial literacy has a significant effect on the disposition bias of mutual fund investors.

2. Risk attitude has a significant impact on the disposition bias of mutual fund investors.

3. Saving motives have a substantial effect on the disposition bias of mutual fund investors.

\section{METHODOLOGY}

The type of research used is associative research. The data collection method is online questionnaire distribution using google forms. The population in this study is Indonesian people. A sample of 100 (one hundred) was taken using the purposive sampling method, with sample criteria such as:

a. Mutual fund investors

b. The decision to sell mutual funds come from the respondents themselves.

The operational definitions of the research variables are as follows:

a. Disposition Bias (DB) is the behavior of investors who are shown in the decision to sell assets when prices rise and not to sell assets when prices fall (Ackert and Deaves, 2010).

b. Financial Literacy (FL) is the capacity of evaluating new and complex financial instruments and making judgments on financial instruments (Mandell, 2007). 
c. Risk Attitude (RA) is an action chosen based on the idea of uncertainty that affects the goal, namely the attitude to accept and face risk (Rohrmann, 2004).

d. Saving Motives (SM) refers to a situation where individuals save to prepare for future needs (Keynes, 1936).

The data analysis technique used is binary logistic regression. The steps that need to be done are validity test, reliability test, regression analysis: Hosmer and Lemeshow Goodness of Fit Test, Coefficient of Determination, Classification Matrix, Hypothesis Test (Variables in The Equations).

\section{ANALYSIS AND DISCUSSION}

\section{Validity Test}

Testing the variable disposition bias involves three questions that produce Pearson Correlation 0.917; 0.871 ; and 0.8624 . These three results are in accordance with the test conditions, which are greater than 0.1824 . Therefore, the three indicators of the variable disposition bias in this study were declared valid.

\section{Reliability Test}

Table 1. Reliability Test Results

\begin{tabular}{lllll}
\hline No & Variable & Cronbach alpha & Critical Value & Criteria \\
\hline 1 & Disposition Bias & 0.860 & 0.60 & Reliable \\
2 & Financial Literacy & 0.830 & 0.60 & Reliable \\
3 & Risk Attitude & 0.808 & 0.60 & Reliable \\
4 & Saving Motives & 0.845 & 0.60 & Reliable \\
\hline
\end{tabular}

Based on the table results above, it is found that the Cronbach alpha of each variable was greater than 0.60 . This shows that the respondent's answer is declared reliable, so one can judge that the respondent is consistent in answering the questionnaire.

\section{Regression Analysis}

1) Hosmer and Lemeshow

Table 2. Hosmer and Lemeshow Test Results

\begin{tabular}{llll}
\hline & DB (1) & DB (2) & DB (3) \\
\hline Chi-square & 0.088 & 0.569 & 0.818 \\
\hline
\end{tabular}

The three Chi-square results above show that the significance value of Chi-Square is more than 0.05 . Therefore the decisions taken in the regression equation are feasible to use.

2) Determination Coefficient

Table 3. Determination Coefficient Test Results

\begin{tabular}{llll}
\hline & DB (1) & DB (2) & DB (3) \\
\hline Nagelkerke R square & 0.530 & 0.209 & 0.385 \\
\hline
\end{tabular}

Nagelkerke $\mathrm{R}$ square states that the independent variables of $53 \%$ can explain the disposition bias (1). The second result is the disposition bias (2) which presents at $20.9 \%$, and the final product can be defined by $38.5 \%$ by financial literacy, risk attitude, and saving motives.

3) Classification Matrix

Table 4. Disposition Test ResultsBias

\begin{tabular}{llccc}
\hline \multicolumn{2}{c}{ Observed } & \multicolumn{3}{c}{ Predicted } \\
\cline { 3 - 5 } & & Low & High & Percentage Correct \\
\hline Disposition Bias 1 & Low & 42 & 12 & 77.8 \\
& High & 7 & 55 & 88.7 \\
\hline Overall Percentage & & & 83.6 \\
\hline Disposition Bias 2 & Low & 57 & 12 & 82.6 \\
& High & 25 & 22 & 46.8 \\
\hline Overall Percentage & & & 68.1 \\
\hline Disposition Bias 3 & Low & 32 & 19 & 62.7 \\
& High & 9 & 56 & 86.2 \\
\hline \multicolumn{2}{l}{ Overall Percentage } & & & 75.9 \\
\hline
\end{tabular}


Disposition bias (1) has a value of $83.6 \%$, disposition bias (2) is $68.1 \%$, and disposition bias (3) has a value of $75.9 \%$. These three results indicate that the logistic regression reflects the actual situation.

\section{Hypothesis Testing}

Hypothesis testing is carried out using logistic regression concerning the significant level used at 0.05 or $5 \%$. If the significance value is less than 0.05 , then $\mathrm{H}_{0}$ is rejected. Based on the significance level, the $\mathrm{FL}$ and RA variables have a significant effect on the DB variable. The variable SM does not have a significant impact on DB. Further discussion analysis regarding the results of hypothesis testing is as follows:

According to Jonsson et al. (2017), investors who know mutual funds affect investors' tendency to sell mutual funds with poor performance. Someone with a low level of financial literacy will not immediately sell their mutual funds if it is known that the price has decreased. This type of investor does not consider the current or the future economic situation through some of the available information. Investors tend to panic immediately and do not sell mutual fund assets whose value decreases because they expect an increase in the investment value. Investors with a high level of financial literacy will not hold their assets if the price decreases; this is because investors will consider various decision options before making a sale which is influenced by the knowledge, news, and information that investors have.

Someone who has a high-risk tolerance level or can be said to have a high risk attitude will be more willing to take an existing risk. This study found that the risk attitude of most investors in the low class, which means that investors were not too brave to take risk and significantly affected disposition bias. Most investors will immediately sell their mutual fund assets if the price falls because it is feared that the price could drop even further, and investors do not want to take the risk. The risks that will occur cannot be predicted even though there is a variety of information about the economy; investors do not manage this information correctly, so that they tend to sell assets that have decreased in value. Investors do not want their assets to suffer losses, so investors immediately sell them.

The regression results also show that saving motives had no significant effect on Disposition bias. This is in line with the following research conducted by Leon \& Pringganingrum (2018), which states that saving motives do not affect investors' disposition bias in making mutual fund investment decisions. It was said earlier that saving now for the future requires a choice between spending and saving, sacrificing current consumption to save. A low disposition bias indicates that an investor knows what risks to face and chooses to put their funds in savings assets. Savings are considered as the safest alternative means when an investor has a low bias disposition. The more often someone saves, it can't be said that they understand when making an investment decision.

This suitable research indicates that in one's saving activities, it is not always related to mutual fund investment preferences. Saving is done to meet future needs, so it can be said that someone who saves, both in mutual fund investment options and saves with other options, is someone who saves for the long term. Investors who save for the long term, of course, will not rush into selling their assets even if their value decreases. Investors pay more attention to the future flow of an economy because what they are waiting for is the future results with a relatively long period of time. Investors feel that every time the economy fluctuates, it doesn't indicate that an asset whose value is decreasing will certainly experience loss.

\section{CONCLUSIONS AND RECOMMENDATIONS}

Based on the analysis and discussion that has been done, the researchers found the following conclusions:

1. Financial literacy has a significant effect on the disposition bias of mutual fund investors.

2. Risk attitude has a significant effect on the disposition bias of mutual fund investors.

3. Saving motives do not have a significant effect on disposition bases mutual fund investors. 
Based on the results of the research and the conclusions obtained, the suggestions that can convey are as follows:

1. Investors and potential mutual fund investors should consider carefully, do not rush, and pay attention to mutual fund news, as well as individual risk profiles when they want to decide to sell. Investors were buying mutual funds because if you make a wrong decision, it will impact or result from what you want.

2. Asset management can suggest mutual fund products to investors and prospective investors according to their financial literacy and risk attitude needs.

3. For future researchers, the drawbacks of this study are it does not use demographic variables and does not examine the three conditions in the indicator disposition bias separately. The results of disposition bias for mutual fund investor cannot be specifically explained.

\section{REFERENCES}

Awan, HM, \& Arshad, S. (2012). Factors Valued by Investors While Investing in Mutual Funds. Interdisciplinary Journal of Contemporary Research in Business, 504.

Charness, G. Gneezy, U., 2007. Strong gender differences in investment. Mimeo

Chowdhury, S. \& Endres, M. (2005). Gender difference and the formation of entrepreneurial self-efficacy. Presented at the United States Association of Small Business (USASBE) Annual Conference, Indian Wells, CA.

Dhavaney, S et al (2007). Household Saving Motive, The Journal of Consumer Affairs, Vol. 41. No. 1.pp. 174-186.

Friestad, Marian and Peter Wright (1994), "The Persuasion Knowledge Model: How People Cope with Persuasion Attempts," Journal of Consumer Research, 21 (June), 1-31.

Grable, J., \& Lytton, RH (1999). Financial risk tolerance revisited: The development of a risk assessment instrument. Financial Sendees Review, 8, 163-181.

Harris, CR, Jenkins, M., \& Glaser, D. (2006). Gender differences in risk assessment: Why do women take fewer risks than men? Judgment and Decision Making, 1, 48-63.

Hillson DA \& Murray-Webster R. 2005. "Understanding and managing risk attitude using applied emotional literacy". Published by Gower, Aldershot, UK. ISBN 0-566-08627-1 (forthcoming).

Kafayat, A. (2014). Interrelationship of Biases: Effect Investment Decisions Ultimately. Theoretical and Applied Economics XXI 6 (595), 85-110.

Kahneman, D \& Tversky, A. (1979). 'Prospect theory: An analysis of decision under risk', Econometrica, vol. 47, no. 2, pp. 263-291. http://dx.doi.org/10.2307/1914185.

Keynes, JM (1936). The general theory of employment, interest and money. London: Macmillan.

Lusardi, A, Olivia S. Mitchell, and Curto, V. 2010. Financial Literacy among the Young. Journal of Consumer Affairs, 44 (2): 358-380.

Mahdzan, NS, \& Tabiani, S. (2013). The Impact of Financial Literacy on Individual Saving: An Exploratory Study In The Malaysian Context. Transformations in Business and Economics, 12(1).

Mandell, L. (2008), The Financial Literacy of Young American Adults: Results of the 2008 National Jump \$ Tart Coalition Survey of High School Seniors and College Students, The Jump \$tart Coalition for Personal Financial Literacy, Washington.

Pompian, Michael M. (2006). Behavioral Finance and Wealth Management. How to Build Optimal Portfolios That Account for Investor Biases. First Edition. New Jersey: John Wiley \& Sons, Inc .

Powell, M., \& Ansic, D. (1997). Gender differences in risk behaviour in financial decision-making: an experimental analysis. Journal of Economic Psychology, 18, $605-628$.

Ricciardi, V. \& Simon, HK (2000). What is Behavioral Finance? Business, Education and Technology Journal, pp. 19.

Wahono, H. K. \& Pertiwi, D. (2020). Pengaruh financial literacy, materialism, compulsive buying terhadap propensity to indebtedness. International Journal of Financial and Investment Studies (IJFIS), 1(1), 1-14. https://doi.org/10.9744//jifis.1.1.1-14

Wärneryd, K. (1999). The psychology of saving. A study of economic psychology. Cheltenham: Edward Elgar Publishing.

Widjaja, R. \& Pertiwi, D. (2021). The influence of emotional factors, materialism, risk perception, and financial literacy on the tendency of debt of millennial generation in Surabaya. International Journal of Financial and Investment Studies (IJFIS), 1(2), 85-93. Retrieved from https://ojs.petra.ac.id/ijis/index.php/ijfis/article/view/57 